\title{
Effect of Developing Coordination Abilities on Improving Performance Level for Gymnastics for All Shows Players
}

\author{
Samir Abdul Nabi Issa ${ }^{1}$ \\ ${ }^{1}$ Assistant Professor at the Exercises and Gymnastics Training Department, Faculty of Physical Education for Men, Alexandria \\ University, Egypt
}

\begin{abstract}
This research aimed at identify the effect of developing coordination abilities on improving performance level for gymnastics for all shows players in Smouha Sport Social Club. Experimental approach used for one group and pre-post measurements. The study applied on (36) athletes from the mixed team (boys and girls) in Smouha Sport Social club. The most important results showed presence of statistically significant differences between pre and post measurements for coordination abilities and some elements of Gymnastic for all shows' performance level in favor of post measurement. The study recommended to give concern to develop coordination abilities within gymnastics for all shows' players on different teams (boys, girls and mixed (boys and girls)).
\end{abstract}

\section{Introduction}

$\mathrm{G}$ ymnastics for all shows is sport activity with special Inature, it includes a set of acrobatic and gymnastic skills linked to each other to make movement phrase commensurate with device, which used in performance. Due to this sport difficulty, it require special skill, physical, psychological and mental skills, bringing this sport players up to world level require painstaking effort from integrated team plan and implement to get players access the desired international level. (Zaghloul, 2003, 23)

Egyptian Gymnastic Federation (2007, 3) indicated that Gymnastics for All (GG) is a type of gymnastics, which includes dynamic groups include artistic and rhythmic gymnastics as well as linking different movements formations and using music and clothes that reflect show's idea

Zaghloul and Mouawad $(2002,21)$ argue that Gymnastics for All is different from the rest of Gymnastics branches; it has an official competition hold by International Gymnastic Federation every four years. It looks like international gymnastic festivals. Each country has the right to hold this festival annually and invite different countries, this festival is hold in form of different sports shows (in halls, in open courts, in streets and squares.

Khalifa, Labib and Al-Khatib (2003, 118) indicate that Gymnastics for All has arisen under the socio-cultural idea with implicit economic motives in order to spread peace and bringing people together.

Zaghloul (2007, 1), and Shehata, M.I \& Sghazli (2010, 35 36) explain that Gymnastics for All is an educational activity, works to give opportunity for different ages and both sexes to participate in it. There is a chance for everyone as it is a choice for health, recreation, happiness and human relations among peoples and a chance for innovation and creativity within the limits of private abilities.

Gymnastics for all and generally aims to develop health, fitness and social cooperation, and contribute to development of proper physical and psychological life, so gymnastics for all is seeking to achieve physical, skill, social, psychological, mental and recreational goals. (Shaaban, 2013, 2)

Coordination abilities are abilities linked directly to movements and mental and rhythmic aspects, through it, individual can control motor performance and be able perform movements consistently and economically. (Shaaban, 2007, 8)

Coordination abilities are of the most important variables involved in motor skills learning, especially complex skills. Individual who owns the appropriate amount of coordination abilities has multi-expertise to meet new educational situations; it is an assistant and sufficient factor to improve learning process. (Abdulmaksoud, 1994, 49)

Good level of coordination abilities means that movement direction will have a high accuracy level and lead to happiness in motor duties performance for ease of movement performance with multi-mobility abilities beside savings effort. (Khatab, 1997, 537)

Coordination abilities for sport skill performance determined in balance ability, ability to adopt with varied positions, motor connectivity ability, ability to make the 
proper effort, motor rhythmic ability, ability to assess the situation, and rapid response ability. (Abdulmaksoud, 1994, 62)

The nervous system is the main responsible system for achieving high level of coordination abilities through work of sensory receptors, motor nerve cells, individual motor memory, motor reaction speed and neuromuscular coordination within and between muscles. (Abdul Khaliq, 2005, 146)

The researcher - through his work as Gymnastics for all coach in Smouha Sports club - noticed significant decrease in most players' performance level, which attributed to weakness in coordination abilities, because of neglecting coordination abilities development exercises, the matter affect players' marks in periodic evaluation using republic championship evaluation form (appendix 3). This prompted the researcher to implement special exercise program to develop coordination abilities and identify its effect on improving of the level of performance of performance level for gymnastics for all shows players.

\section{Research Objective}

This research aims at identify the effect of developing coordination abilities on improving performance level for gymnastics for all shows players.

\section{Research Hypotheses}

- There are significant differences between pre and post measurement of coordination abilities in favor of post measurement.

- There are significant differences between pre and post measurement of Gymnastic for all performance level in favor of post measurement

\section{Research Terms}

\section{Coordination abilities:}

It is a set of required abilities, which related to physical, mental and rhythmic aspect in order to perform movement's in harmonized manner with saving effort. (Barham \& Abu Smara, 1995, 35)

\section{Gymnastics for All Shows:}

A types of movement activities presented in form of group shows accompanied with music or songs, either with or without tools, to be performed by males, females, or both with different abilities and age stages (Egyptian Gymnastic Federation, 2000, 212)

\section{Research procedures}

\section{Research Methodology:}

The researcher used experimental approach as it suits research the nature

\section{Experimental Design:}

The researcher used one group experimental design, as the main research objective is to internally evaluate sports show and identify its effect on developing coordination abilities.

\section{Research sample:}

(36) Athletes selected randomly from the mixed team (boys and girls) in Smouha Sport Social club. Pilot studies implemented on (20) athletes selected intentionally, total athletes is (84) athlete.

\section{Research domains:}

Spatial domain: Smouha Sporting Social Club Hall in Alexandria.

Time Domain: The study conducted in the period from 22.03.2015 to 26.06.2015 as follows:

- Pilot studies in the period from 22.03.2015 to 04.04.2015.

- Pre measurements in the period from 05.04.2015 to 11.04.2015.

- Main study conducted in the period from 12.04.2015 to 19.04.2015.

- Pre measurement fir sports show performance level on 10.05.2015.

- Post measurements in the period from 21.04.2015 to 26.04.2015 conducted.

\section{Human domain:}

Gymnasts for all show athletes under 15 years of in Smouha Sporting Club.

\section{Data collection tools:}

(a) Coordination abilities test. (Appendix 2)

(b) Gymnastics for all evaluation form (appendix 3): The Republic Championship Evaluation Form presented to experts (appendix 4) to determine the most related elements to coordination abilities. 


\section{Pilot studies}

\section{First pilot study:}

Objective find validity and reliability of coordination abilities tests(Appendix 1).

\section{Second pilot study:}

This study aimed at identify Gymnastic for All Evaluation form elements which most related to coordination abilities through presenting it to experts (appendic 5).

\section{Sample homogeneity:}

Table 1

Statistical significance for basic variables and coordination abilities for research sample $(n=36)$

\begin{tabular}{|c|c|c|c|c|c|c|c|}
\hline \multicolumn{2}{|l|}{ variables } & $\begin{array}{c}\text { Measurement } \\
\text { unit }\end{array}$ & Mean & $\pm \mathrm{SD}$ & skewness & Kurtosis & $\begin{array}{l}\text { Variance } \\
\text { coefficient }\end{array}$ \\
\hline \multicolumn{2}{|c|}{ Age } & (year) & 13.16 & .54 & 0.85 & 1.33 & 0.41 \\
\hline \multicolumn{2}{|c|}{ Height } & $(\mathrm{cm})$ & 135.55 & .25 & 0.98 & 0.58 & 0.24 \\
\hline \multicolumn{2}{|c|}{ Weight } & $(\mathrm{Kg})$ & 30.58 & .02 & 1.17 & -1.05 & 0.33 \\
\hline \multicolumn{2}{|c|}{ Training age } & (year) & 7.24 & .58 & 1.25 & -1.36 & 0.80 \\
\hline Stable balance ability & $\begin{array}{c}\text { Standing with instep on } \\
\text { cube }\end{array}$ & (seconds) & 8.37 & .01 & 0.15 & $1.53-$ & 12.11 \\
\hline Moving balance ability & walk on balance beam & (seconds) & 10.22 & .64 & 1.85 & 2.89 & 15.99 \\
\hline $\begin{array}{l}\text { ability to adapt with } \\
\text { changing positions }\end{array}$ & $\begin{array}{l}\text { slant prostration from } \\
\text { standing ( } 10 \text { seconds) }\end{array}$ & (number) & 5.80 & .79 & $0.57-$ & 0.70 & 13.65 \\
\hline $\begin{array}{c}\text { ability to motor } \\
\text { connectivity }\end{array}$ & rope jump (10 seconds) & (number) & 14.56 & .19 & $1.00-$ & $0.42-$ & 8.19 \\
\hline $\begin{array}{c}\text { ability to make proper } \\
\text { effort }\end{array}$ & $\begin{array}{l}\text { Shooting by hand on } \\
\text { overlapped rectangles }\end{array}$ & (marks) & 14.29 & .71 & $1.74-$ & 2.21 & 5.00 \\
\hline motor rhythmic ability & numbered circles & (seconds) & 9.15 & .54 & -1.00 & 1.10 & 5.89 \\
\hline ability to assess position & barriers running & (seconds) & 24.09 & 0.72 & 0.43 & $1.76-$ & 2.99 \\
\hline \multirow{2}{*}{ ability to Fast response } & $\begin{array}{l}\text { reaction speed eye/hand } \\
\text { (right) }\end{array}$ & $(\mathrm{cm})$ & 19.36 & 0.64 & 0.65 & 0.69 & 3.32 \\
\hline & $\begin{array}{c}\text { reaction speed eye/hand } \\
\text { (left) }\end{array}$ & $(\mathrm{cm})$ & 22.23 & 0.93 & 0.36 & 0.55 & 4.18 \\
\hline
\end{tabular}

Table (1) results show skewness coefficients between ($1.74)$ and (1.85) and kurtosis coefficient between (-1.76) and (2.89), values which between \pm 3 shows that sample is free from abnormal distributions defects. Variance coefficients were between $(0.24 \%)$ and $(15.99 \%)$ which is less than the $(20 \%)$ indicate sample homogeneity in all variables under consideration.

\section{Sports Show evaluation:}

Sports show evaluated using the form prepared by Egyptian Gymnastic Federation (appendic 3), Then items related to coordination abilities according to experts' opinion developed through developing coordination abilities

\section{Main experiment:}

The experimental group undergone an educational training program for sports show.

\section{The educational training program for sports show}

- In 1st week, research sample undergone teaching formation and exercises and apply it.

- Starting from 2nd week, research sample undergone : training with revision of positions and correct mistakes
High/Low intensity periodical training used with wheat commensurate with age stage; that continued for 10 weeks, with four weekly training sessions, each educational training session time is (3) hours.

- Total educational training sessions is (40) sessions i.e. (120) learning/training hours.

- Load/rest principle used as base of training on show skills and exercises.

- Each exercise is average performance time equal to 30 seconds.

- Training exercises per unit equal to eight exercises.

- Group repetition is 3 times according to pulse rate and lactate threshold.

- Transition time between exercises ranged between 15 and 45 seconds.

- Rest time between groups ranged between 3 and 5 minutes.

- Sports Show time is (5) minutes, consists of entrance (16) formations - Exit

- Each formation Average performance time equal to (20) seconds.

- Rest time average between formations ranged between (30) and (45) seconds

- Average rest time between performing formation groups in training session ranged between (3) and (5) minutes. 
- Average rest time between full show performance and re-performance ranged between (5 s) and (15) minutes.

Figure 1

Distributing training loads among training program

\begin{tabular}{|c|c|c|c|c|c|c|c|c|c|c|c|}
\hline \multicolumn{2}{|r|}{ Intensity } & 1st & 2nd & 3rd & 4th & 5th & 6th & 7th & 8th & 9 th & 11th \\
\hline Maximum & $90-100 \%$ & & & & & & & & & & \\
\hline High & $70-80 \%$ & & & & & & & & & & \\
\hline Average & $50-60 \%$ & - & & & & & & & & & \\
\hline
\end{tabular}

\section{Statistics used:}

Statistical work carried out using (SPSS) software to extract the following:

- Kurtosis coefficient.

- Validity coefficient.

- Standard deviation

- Variance Coefficient.
- Mean.

- Percentages.

- Skewness coefficient.

- Correlation coefficient.

- "T" paired test.

\section{Results and Discussion}

\section{Results:}

Table 2

Statistical significance for pre and post comparison of coordination tests within research sample $(\mathrm{n}=36)$

\begin{tabular}{|c|c|c|c|c|c|c|c|c|c|c|}
\hline \multirow{2}{*}{\multicolumn{2}{|c|}{$\mathrm{P}_{\text {coordination abilities }}^{\text {Statistics }}$}} & \multirow{2}{*}{$\begin{array}{l}\text { Measurement } \\
\text { unit }\end{array}$} & \multicolumn{2}{|c|}{$\begin{array}{c}\text { Pre } \\
\text { Measurement }\end{array}$} & \multicolumn{2}{|c|}{$\begin{array}{c}\text { Post } \\
\text { Measurement }\end{array}$} & \multirow{2}{*}{$\begin{array}{c}\text { Mean } \\
\text { differences }\end{array}$} & \multirow{2}{*}{$\begin{array}{l}\text { Differences } \\
\text { Deviation }\end{array}$} & \multirow{2}{*}{$\begin{array}{c}(\mathrm{T}) \\
\text { valve }\end{array}$} & \multirow{2}{*}{$\begin{array}{c}\text { Improvement } \\
\%\end{array}$} \\
\hline & & & Mean & $\pm \mathrm{SD}$ & Mean & $\pm \mathrm{SD}$ & & & & \\
\hline $\begin{array}{c}\text { Stable } \\
\text { balance } \\
\text { ability }\end{array}$ & $\begin{array}{c}\text { Standing } \\
\text { with instep } \\
\text { on cube }\end{array}$ & (seconds) & 8.37 & 1.01 & 5.00 & 4.40 & $6.62-$ & 4.12 & $9.64 *$ & $79.10 \%$ \\
\hline $\begin{array}{l}\text { Moving } \\
\text { balance } \\
\text { ability }\end{array}$ & $\begin{array}{c}\text { walk on } \\
\text { balance } \\
\text { beam }\end{array}$ & (seconds) & 10.22 & 1.64 & 6.74 & 0.83 & 3.48 & 1.90 & $11.00 *$ & $34.08 \%$ \\
\hline $\begin{array}{l}\text { ability to } \\
\text { adapt with } \\
\text { changing } \\
\text { positions }\end{array}$ & $\begin{array}{c}\text { slant } \\
\text { prostration } \\
\text { from } \\
\text { standing } \\
(10 \\
\text { seconds }) \\
\end{array}$ & (number) & 5.80 & 0.79 & 9.55 & 1.25 & $3.75-$ & 1.33 & $16.98 *$ & $64.76 \%$ \\
\hline $\begin{array}{l}\text { ability to } \\
\text { motor } \\
\text { connectivity }\end{array}$ & $\begin{array}{c}\text { rope jump } \\
(10 \\
\text { seconds })\end{array}$ & (number) & 14.56 & 1.19 & 8.65 & 0.33 & $4.09-$ & 1.12 & $21.85^{*}$ & $28.13 \%$ \\
\hline $\begin{array}{l}\text { ability to } \\
\text { make proper } \\
\text { effort }\end{array}$ & $\begin{array}{l}\text { Shooting } \\
\text { by hand on } \\
\text { overlapped } \\
\text { rectangles }\end{array}$ & (marks) & 14.29 & 0.71 & 9.72 & 0.27 & $5.43-$ & 0.76 & $42.64 *$ & $37.99 \%$ \\
\hline $\begin{array}{l}\text { motor } \\
\text { rhythmic } \\
\text { ability }\end{array}$ & $\begin{array}{l}\text { numbered } \\
\text { circles }\end{array}$ & (seconds) & 9.15 & 0.54 & 6.19 & 0.92 & 2.96 & 1.20 & $14.76^{*}$ & $32.37 \%$ \\
\hline $\begin{array}{l}\text { ability to } \\
\text { assess } \\
\text { position }\end{array}$ & $\begin{array}{l}\text { barriers } \\
\text { running }\end{array}$ & (seconds) & 24.09 & 0.72 & 8.91 & 1.15 & 5.18 & 1.10 & $28.33^{*}$ & $21.49 \%$ \\
\hline \multirow{2}{*}{$\begin{array}{l}\text { ability to } \\
\text { Fast } \\
\text { response }\end{array}$} & $\begin{array}{l}\text { reaction } \\
\text { speed } \\
\text { eye/hand } \\
\text { (right) } \\
\end{array}$ & $(\mathrm{cm})$ & 19.36 & 0.64 & 8.21 & 0.35 & 11.16 & 0.50 & $\begin{array}{c}132.91 \\
*\end{array}$ & $57.61 \%$ \\
\hline & $\begin{array}{l}\text { reaction } \\
\text { speed } \\
\text { eye/hand } \\
\text { (left) }\end{array}$ & $(\mathrm{cm})$ & 22.23 & 0.93 & 9.43 & 0.49 & 12.80 & 1.07 & $71.52 *$ & $57.58 \%$ \\
\hline
\end{tabular}

( $\mathrm{T}$ ) significant at 0.05 level $=2.030$ 
Figure 2

Pre and post means of coordination tests within research sample

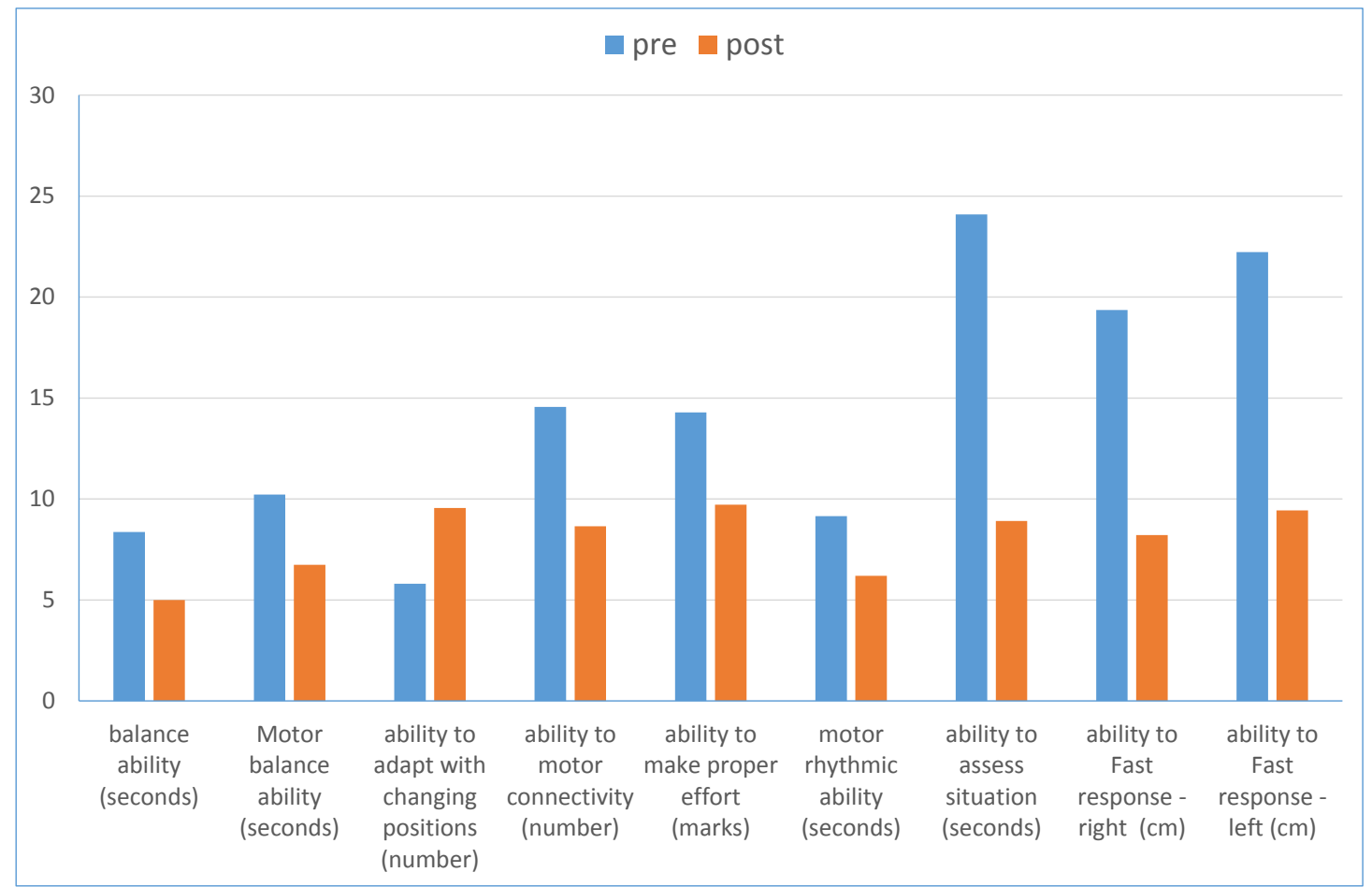

Table (2) and Figure (2) results reveal statistically significant differences at 0.05 level between pre and post measurement for all coordination abilities in favor of post experiment. T value ranged between (9.64 and 132.91), and improvement percentage ranged between $(21.49 \%$ and measurement i.e. all coordination abilities improved after $79.10 \%)$

Table 3

Statistical significance for pre and post comparison of gymnastics for all shows evaluation elements

\begin{tabular}{|c|c|c|c|c|c|c|c|c|c|}
\hline \multirow{2}{*}{ coordination abilities } & \multirow{2}{*}{$\begin{array}{c}\text { Measur } \\
\text { ement } \\
\text { unit }\end{array}$} & \multicolumn{2}{|c|}{$\begin{array}{c}\text { Pre } \\
\text { Measurement } \\
\end{array}$} & \multicolumn{2}{|c|}{$\begin{array}{c}\text { Post } \\
\text { Measurement } \\
\end{array}$} & \multirow{2}{*}{$\begin{array}{c}\text { Mean } \\
\text { differences }\end{array}$} & \multirow{2}{*}{$\begin{array}{l}\text { Differe } \\
\text { nces } \\
\text { Deviati } \\
\text { on } \\
\end{array}$} & \multirow{2}{*}{$\begin{array}{l}(\mathrm{T}) \\
\text { valve }\end{array}$} & \multirow{2}{*}{$\begin{array}{l}\text { Improve } \\
\text { ment \% }\end{array}$} \\
\hline & & Mean & $\pm \mathrm{SD}$ & Mean & $\pm \mathrm{SD}$ & & & & \\
\hline $\begin{array}{c}\text { Body movements } \\
\text { (difficulties) }\end{array}$ & \multirow{8}{*}{ 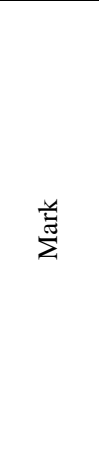 } & 4.60 & 0.55 & 9.40 & 0.55 & $4.80-$ & 0.84 & $* 12.83$ & $104.35 \%$ \\
\hline Group performance unity & & 4.60 & 0.55 & 9.30 & 0.55 & $4.70-$ & 0.74 & $* 12.73$ & $102.17 \%$ \\
\hline $\begin{array}{l}\text { Skills and exercises } \\
\text { appropriateness for age } \\
\text { stage }\end{array}$ & & 1.90 & 0.22 & 4.98 & 0.04 & $3.08-$ & 0.18 & $* 38.50$ & $162.11 \%$ \\
\hline $\begin{array}{c}\text { Innovation and super } \\
\text { performance }\end{array}$ & & 1.92 & 0.08 & 4.96 & 0.09 & $3.04-$ & 0.15 & $44.82 *$ & $158.33 \%$ \\
\hline $\begin{array}{c}\text { Motor performance } \\
\text { harmonization with music }\end{array}$ & & 4.60 & 0.55 & 9.86 & 0.22 & $5.26-$ & 0.62 & $18.88^{*}$ & $114.35 \%$ \\
\hline Formations & & 4.91 & 0.12 & 9.78 & 0.18 & $4.87-$ & 0.23 & $47.75 *$ & $99.19 \%$ \\
\hline Entrance & & 0.84 & 0.11 & 2.90 & 0.07 & $2.06-$ & 0.09 & $51.50 *$ & $245.24 \%$ \\
\hline Exit & & 0.58 & 0.10 & 1.99 & 0.02 & $1.41-$ & 0.14 & $21.95 *$ & $242.76 \%$ \\
\hline
\end{tabular}

(T) significant at 0.05 level $=2.030$ 
Figure 3

Pre and post means of gymnastics for all shows evaluation elements

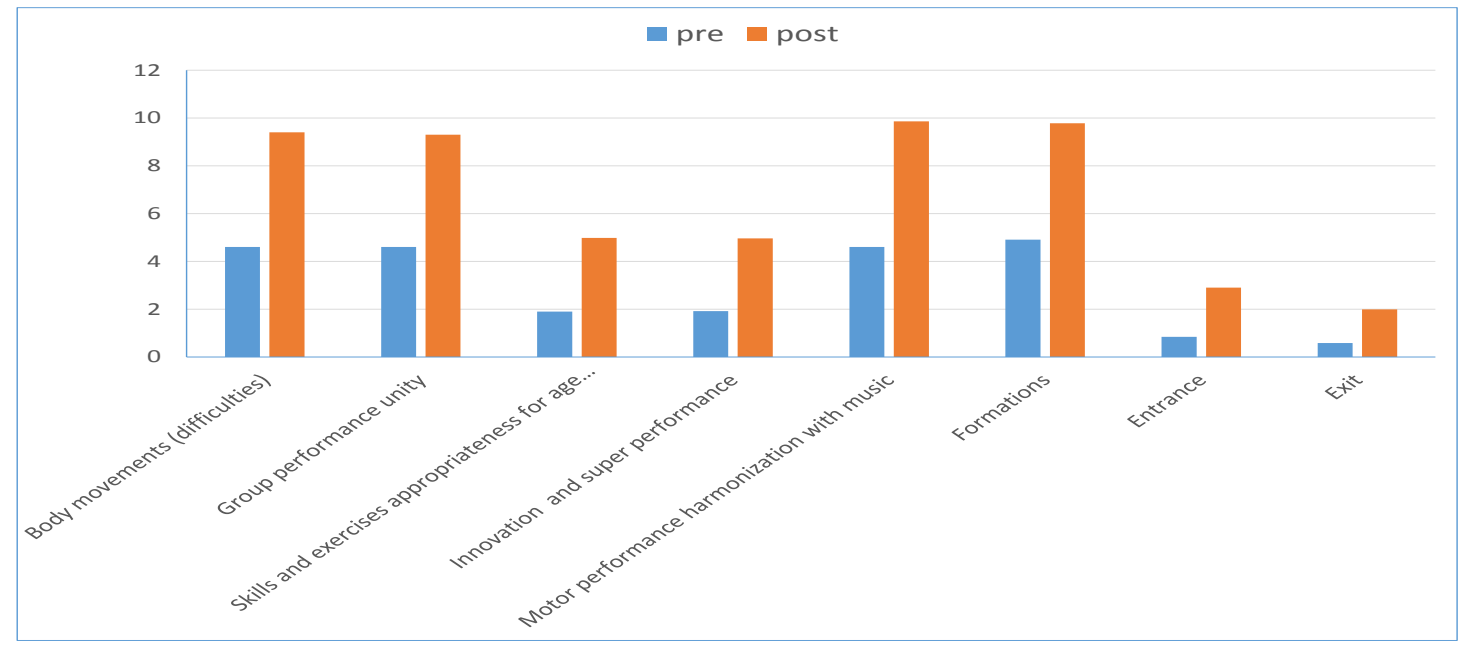

Table (3) and Figure (3) results reveal statistically significant differences at 0.05 level between pre and post measurement for all gymnastics for all shows evaluation elements in favor of post measurement i.e. all elements improved after experiment. $\mathrm{T}$ value ranged between (12.73 and 51.50), and improvement percentage ranged between $(99.19 \%$ and $245.24 \%)$

\section{Discussion:}

There are significant differences between pre and post measurements in favor of post measurement in all coordination abilities within Gymnastics for all shows players, which researcher attribute to the shows proposed educational training program with standardized intensity and load. Standardized training, which is based on sound scientific bases work on developing coordination abilities (Salem \& Shaaban, 2009, 9)

The researcher also attribute this difference also to the effectiveness of exercise used in gymnastic for all show for mixed team (boys and girls), which directed to developing coordination abilities. Abdulmaksoud (1994, 186) indicated that developing coordination abilities basis is varied motor performance, which include each component of these abilities, so exercises must be chosen objectively.

Muhammad (2007, 67)explains that exercise practicing is the primary way for developing coordination abilities, by changing the motor performance in terms of direction, volume, effort and timing.)

The researcher argue that using umbrellas and exercise tools in exercises were effective in terms of connectivity, transitional movements, agility, coordination and the two types of balance.
Physical exercises using tools help in physical and psychological preparation to accept more effort and increase enthusiasm and willingness to practice and performance. It also increases the thrill and excitement. This is in line with what mentioned by Barham \& Abu Smara (1995, 25-26), Khatab (1997, 23-25), Abu Hrja, Zaghloul \& Radwan, 2000, 54) and (Al-Shazly \& BuAbas, 2001, 14-15) that exercises using tools are important in developing sports level.

This confirmed by study results of Marei (1997), and Muhammad $(2002,2007)$ which indicated that using tools in exercises help to improve physical abiliuties in general, and in particular, neuromuscular coordination, balance, agility and flexibility.

There are, also, significant differences between pre and post measurements in favor of post measurement in motor routine evaluation elements, which researcher attribute to nature of the proposed educational training program, as well as that structured training and repetition of sports show movements' performance led to the improvement and development of motor performance level. This is consistent with study results of Mahmoud (2004), and Salem \& Shaaban (2008) (6), and Shaaban (2013).

Fuerst, M \& Levy. A (1993, 135) emphasized that using music during physical performance has effective influence as a way to organize and control performance, and bring fun and excitement to work, the matter which helps to delay fatigue onset. This is confirmed by Salem \& Shaaban $(2008,121)$ study results which revealed that training with music have positive effect on students' learning speed and progress in technical performance.

Music rhythm has major effect on movement; it is involved in developing a movement sense, improve performance, delay fatigue onset, and helping to smooth 
movements. Music rhythm is important to master motor skills and access control level of movements. (Zahran, 1997, 99) (Abdulmaksoud, 1994, 121)

$\mathrm{n}$ this regard refers Rosser $(1995,231)$ indicates that choosing music accompanying the exercises is of the necessities of load preparation and planning, because of what exercise practice require from continuous practice in proper time

\section{Conclusions}

1. Experimental group improved in post measurement in all coordination abilities under study, Improvement order from high to low was as follows: (stable balance ability, ability to adapt with changing positions, ability to fast response [eye/hand left and right], ability to make proper effort, moving balance ability, motor rhythmic ability, ability to motor connectivity, and at last ability to assess position)

2. Experimental group improved in post measurement in all gymnastic for all show's evaluation elements, Improvement order from high to low was as follows (Entrance, Exit, Skills and exercises appropriateness for age stage, Innovation and super performance, Motor performance harmonization with music, Body movements (difficulties), Group performance unity, and at last formations)

3. Developing coordination abilities led to improvement in performance level in gymnastic for all shows' evaluation elements.

\section{Recommendations}

1. Attention to be given to development of coordination abilities to improve performance level of Gymnastics for shows for the different teams (boys, girls and mixed)

2. Selecting proper exercises, which achieve the object, should be taken into account while developing coordination abilities.

3. Encourage players to participate in gymnastics for all shows, which contribute to improving coordination abilities they have.

\section{References}

1. Abdul Khaliq, E.M. (2005), sports training, theories and applications. 10th ed. Alexandria: Knowledge House. (In Arabic Language)

2. Abdulmaksoud, S. (1994). Movement theories. Cairo: Youth printing press. (In Arabic Language)

3. Abu Hrja, M. H., Zaghloul, M.S. \& Radwan, M. R.(2000) Encyclopaedia of physical education field training. Cairo:Book publishing center. (In Arabic Language)

4. Allawi, M. H. \& Radwan, M. N. (2001). Motor performance tests Cairo: Arab Thought House. (In Arabic Language)

5. Al-Shazly, A. F. \& Bu-Abas, Y. R. (2001): Scientific basis for teaching physical exercise, Kuwait: That ElSalasil. (In Arabic Language)

6. Barham, A. S. \& Abu Smara, M. K. (1995). Sport exercises Encyclopaedia, part 1, second edition, Cairo: Arab thought for publication and distribution. (In Arabic Language)

7. Egyptian Gymnastics Federation (2000). Technical instructions for the 2000/2001 Artistic Gymnastic Republic championship for boys and girls. Egyptian Gymnastics Federation. (In Arabic Language)

8. Fuerst, M \& Levy. A. (1993). Sport injury hand, professional advice for amateur athletes. New York: Wiley and sons.

9. Hassanein, M. S. (2004). Measurement and Evaluation in Physical Education and Sports. Vol. I. sixth ed. Cairo: Arab Thought house. (In Arabic Language)

10. Khalifa, N., Labib, S. \& Al-Khatib, N. (2003): theoretical and applied foundations in artistic gymnastics, Faculty of Physical Education for Girls, Helwan University. Cairo:Book publishing center (In Arabic Language)

11. Khatab, A. M. (1997). Exercise for girls, eighth edition, Cairo: Knowledge House. (In Arabic Language)

12. Mahmoud, H. A. (2004). Effect of using sport shows on emotional aspect of students at first episode, East Tanta educational district. Master Thesis. Faculty of Physical Education for Men, Alexandria University. . (In Arabic Language

13. Marei, M.I. (1997). Effect of exercise program using one of educational technology means on some variables associated with compulsory exercises routine for students at Faculty of Physical Education. Master Thesis. Faculty of Physical Education for Men, Alexandria University. . (In Arabic Language)

14. Muhammad, M. A. (2002). Effect of standardized exercise routine with rope on developing some motor abilities of students at Faculty of Physical Education. Master Thesis. Faculty of Physical Education for Men, Alexandria University. (In Arabic Language)

15. Muhammad, M. A. (2007). Effect of developing some coordination abilities on performance level of exercises movement skills with tools. Ph.D. thesis. Faculty of Physical Education for Men, University of Alexandria 0.2007. (In Arabic Language) 
16. Nabih, M.M. (2004). Effect of developing some coordination abilities on raising technical performance level on balance beam within junior female gymnasts under 8 years, Master Thesis, Faculty of Physical Education for Men, Alexandria University. (In Arabic Language)

17. Rosser, M. (1995).Body Fitness and exercise. London: Hodder and Stoughton educational.

18. Salem, E. M. \& Shaaban, S. A. (2008). The effect of training with music rhythm's speed diversity on performance level in sports shows. Fourth Regional Conference of the International Council for Health, Physical Education, Recreation, Sports and dance for the Middle East, Part II , Faculty of Physical Education for Men, , Alexandria University. (In Arabic Language)

19. Salem, E. M. \& Shaaban, S. A. (2009). Effect of practicing sports shows with on improving some mental state and some coordination abilities within Faculty of Physical Education students. Journal of Physical Education and Sports, Faculty of Physical Education for Girls, Alexandria University. 41:pp39-65. (In Arabic Language)

20. Shaaban, S. A. (2007): The effect of sports shows on the dynamics development of some perception variables (Kinaesthetic) and practical achievement in exercises with tools for students at Faculty of Physical Education. Ph.D. Faculty of Physical Education, Alexandria University. (In Arabic Language)
21. Shaaban, S. A. (2013). the effect of specific exercise on dynamics development of Kinaesthetic Perception of some motor skills for gymnastics of all players, theories and applications, specialized journal in Physical Education and Sports Science. Issue 78. Faculty of Physical Education for men, Alexandria University. (In Arabic Language)

22. Shehata, M.I \& Sghazli, A. (2010): Gymnastics for All guide, Alexandria : Knowledge establishment. . (In Arabic Language)

23. Yousef, S.A. (2001): developing some coordination abilities and its relationship with fencing complex attack's performance. Master Thesis. Faculty of Physical Education for Girls, Zagazig University. (In Arabic Language)

24. Zaghloul, I.S \& Mouawad, S. (2002). Gymnastics basic principles. Cairo: GMS for printing. (in Arabic language)

25. Zaghloul, I.S (2003). World Gymnaestrada between past, present and future. Scientific article. (in Arabic language)

26. Zaghloul, I.S (2007). Concluding 2003 World Gymnaestrada administrative and technical construction. Scientific journal of Physical Education, Faculty of Physical Education for Men, Helwan, issue 39. (in Arabic language)

27. Zahran, L.A. (1997) scientific and applied bases for exercises and technical exercises, Cairo: Arab Thought House. (In Arabic Language) 